\title{
Research Article \\ Effects of Different Doping Ratio of Cu Doped CdS on QDSCs Performance
}

\author{
Xiaojun Zhu, Xiaoping Zou, and Hongquan Zhou \\ Beijing Key Laboratory for Sensor, Ministry-of-Education Key Laboratory for Modern Measurement and Control Technology and \\ School of Applied Sciences, Beijing Information Science and Technology University, Jianxiangqiao Campus, Beijing 100101, China
}

Correspondence should be addressed to Xiaoping Zou; xpzou2005@gmail.com

Received 13 June 2014; Accepted 16 October 2014

Academic Editor: Jin H. Kim

Copyright (C) 2015 Xiaojun Zhu et al. This is an open access article distributed under the Creative Commons Attribution License, which permits unrestricted use, distribution, and reproduction in any medium, provided the original work is properly cited.

We use the successive ionic layer adsorption and reaction (SILAR) method for the preparation of quantum dot sensitized solar cells, to improve the performance of solar cells by doping quantum dots. We tested the UV-Vis absorption spectrum of undoped CdS QDSCs and Cu doped CdS QDSCs with different doping ratios. The doping ratios of copper were 1:100, 1:500, and 1:1000, respectively. The experimental results show that, under the same SILAR cycle number, Cu doped CdS quantum dot sensitized solar cells have higher open circuit voltage, short circuit current density photoelectric conversion efficiency than undoped CdS quantum dots sensitized solar cells. Refinement of Cu doping ratio are $1: 10,1: 100,1: 200,1: 500$, and $1: 1000$. When the proportion of Cu and CdS is $1: 10$, all the parameters of the QDSCs reach the minimum value, and, with the decrease of the proportion, the short circuit current density, open circuit voltage, and the photoelectric conversion efficiency are all increased. When proportion is 1:500, all parameters reach the maximum values. While with further reduction of the doping ratio of $\mathrm{Cu}$, the parameters of QDSCs have a decline tendency. The results showed that, in a certain range, the lower the doping ratio of $\mathrm{Cu}$, the better the performance of quantum dot sensitized solar cell.

\section{Introduction}

Due to rapid growth in the world economy, energy problems have considerable attention in the past several decades [1]. To provide energy alternatives, researchers have been developing renewable energies including solar, nuclear, wind, and biopower [2]. Among these alternatives, solar-to-electric energy conversion systems have always been a fascinating and challenging frontier for science and application [1-3].

Quantum dot sensitized solar cells (QDSCs) are gaining attention as they show promise toward the development of next generation solar cells [4-8]. The design of QDSCs which is similar to that of dye sensitized solar cell (QDSC) includes deposition of narrow bandgap semiconductor nanocrystal such as CdSe on mesoscopic $\mathrm{TiO}_{2}$ films [9]. Although the photocurrent achieved from QDSCs is comparable to that of DSSCs, the observed power conversion efficiency remains quite low because of the low open circuit potential as well as low fill factor [10]. We use the successive ionic layer adsorption and reaction (SILAR) method for the preparation of quantum dot sensitized solar cell to improve the performance of solar cells by doping quantum dots. We tested the UV-Vis absorption spectrum of undoped CdS QDSCs and $\mathrm{Cu}$ doped CdS QDSCs with different doping ratios. The doping ratios of copper were $1: 100,1: 500$, and $1: 1000$. The experimental results show that, under the same SILAR cycle number, $\mathrm{Cu}$ doped $\mathrm{CdS}$ quantum dot sensitized solar cells have higher open circuit voltage, short circuit current density, andphotoelectric conversion efficiency than undoped CdS quantum dots sensitized solar cells.

With the aid of research, we describe a method for improving CdS QDSCs efficiency. The results showed that, in a certain range, the lower the doping ratio of $\mathrm{Cu}$ is, the better the performance of quantum dot sensitized solar cell is.

\section{Experimental Detail}

2.1. Material and Preparation. Chemicals were purchased and used as received. We need $0.1 \mathrm{M} \mathrm{Cd}\left(\mathrm{NO}_{3}\right)_{2}$ ethanol solution and $\mathrm{CuCl}_{2}$ and $0.1 \mathrm{M} \mathrm{Na} \mathrm{Na}_{2} \mathrm{~S}$ methanol solution. 
TABLE 1: ICP-OES test data of $\mathrm{Cu}$ doped CdS quantum dots.

\begin{tabular}{lccccc}
\hline Sample & $\mathrm{Cd}(\mu \mathrm{g})$ & $\mathrm{Cu}(\mu \mathrm{g})$ & $\mathrm{Cd}\left(10^{-6} \mathrm{~mol}\right)$ & $\mathrm{Cu}\left(10^{-6} \mathrm{~mol}\right)$ & The molar ratio of copper \\
\hline $\mathrm{Cu}-\mathrm{CdS}$ & 512 & 8.043 & 4.555 & 0.127 & $2.788 \%$ \\
\hline
\end{tabular}



FIGURE 1: The SEM image of Cu doped CdS quantum dots photoanode; illustration is the EDS spectrum.

The mixed solution includes doping substances and the main precursor; the SILAR method was used to deposit the doped quantum dots.

2.2. Measurements. We added $\mathrm{CuCl}_{2}$ into $0.1 \mathrm{M} \mathrm{Cd}\left(\mathrm{NO}_{3}\right)_{2}$ ethanol solution as the cation precursor solution, and used $0.1 \mathrm{M} \mathrm{Na} \mathrm{S}_{2} \mathrm{~S}$ methanol solution as the anion precursor solution. Then we prepared the $\mathrm{Cu}$ doped $\mathrm{CdS}$ quantum dots by SILAR method. Doping ratio mentioned in this paper refers to the molar ratio of impurity atoms and $\mathrm{Cd}$ atoms in solution preparation, such that the doping ratio of $\mathrm{Cu}$ to $\mathrm{Cd}$ is $1: 100$ which refers to the $\mathrm{CuCl}_{2}$ material $\mathrm{Cu}\left(\mathrm{NO}_{3}\right)_{2}$ molar ratio of $1: 100$, and the deposition method is consistent with specific deposition method for CdS quantum dots.

\section{Results and Discussion}

Figure 1 shows the copper-doped-CdS photoanode SEM image, and the upper right corner of the image block is the corresponding EDS patterns of samples, the copper doping ratio for $1: 100$, SILAR, for 4 times. From the chart component analysis, we can clearly see that copper has been successfully doped into the CdS quantum dot optical anode. But because the $\mathrm{CdS}$ quantum dot size is very small, we cannot see the size of CdS in this graph. As for the morphology of CdS quantum dots, it can be seen in Figure 1, and we will not go into here.

In order to more accurately determine the copper that has been doped into the CdS quantum dots, we conducted inductively coupled plasma atomic emission spectrometry (ICP-OES) test, and the proportion of copper doped here is 1:500, as shown in Table 1 .

In Table 1, the first part is the performance parameters of $\mathrm{Cd}$ and $\mathrm{Cu}$, and the second part is the molar parameters

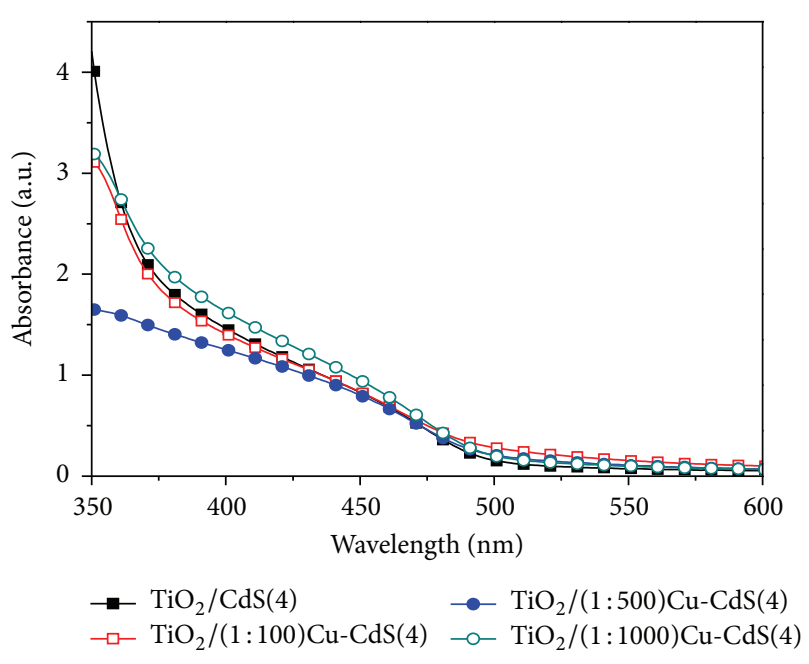

Figure 2: The UV-Vis absorption spectra of $\mathrm{Cu}$ doped $\mathrm{CdS}$ and undoped $\mathrm{CdS}$ with different doping ratio of copper.

of $\mathrm{Cd}$ and $\mathrm{Cu}$ and the molar ratio of $\mathrm{Cu}$ in the $\mathrm{CdS}$. As it can be seen from the table, the molar ratio of copper in prepared solution is $0.2 \%$, but the molar ratio of copper deposition after the share rose to $2.788 \%$, and the content of copper in solid sample increases isnearly 14 times higher than the copper content in the precursor solution. This maybe because, relative to the cadmium ion, copper ion easily reacted with sulfide ion and increased the content of copper and cadmium content decreased.

For the performance of the system of $\mathrm{Cu}$ doped $\mathrm{CdS}$ QDSCs, the effects of doping ratio change CdS properties of QDSCs copper. The UV-V is absorption spectra of Cu doped $\mathrm{CdS}$ quantum dots and undoped CdS quantum dots with different doping ratios of copper; they were $1: 100,1: 500$, and $1: 1000$, respectively (Figure 2 ).

As can be seen from the Figure 2, the absorption spectra of 1:500 $(\mathrm{Cu}: \mathrm{Cd})$ molar ratio of $\mathrm{Cu}$ doped $\mathrm{CdS}$ quantum dots little blue-shift comparing with that of undoped CdS quantum dots and the difference among the three absorption spectra of $\mathrm{Cu}$ doped $\mathrm{CdS}$ quantum dots with different doping ratios is not very significant. The exciton absorption peak is probably around $440 \mathrm{~nm}$. This may be because the three doping ratios are not much different, consistency in their UVVis absorption spectrum is relatively high, and the exciton absorption peaks are almost similar to each other. We should use other ways to represent the characteristics of $\mathrm{Cu}$ doped $\mathrm{CdS}$ quantum dot sensitized solar cell.

The $J-V$ curves of undoped CdS QDSCs and doped-CdS QDSCs with $\mathrm{Cu}$ doping ratio is 1:500 (Figure 3). Table 2 is the performance parameters of the corresponding quantum dot sensitized solar cells. 


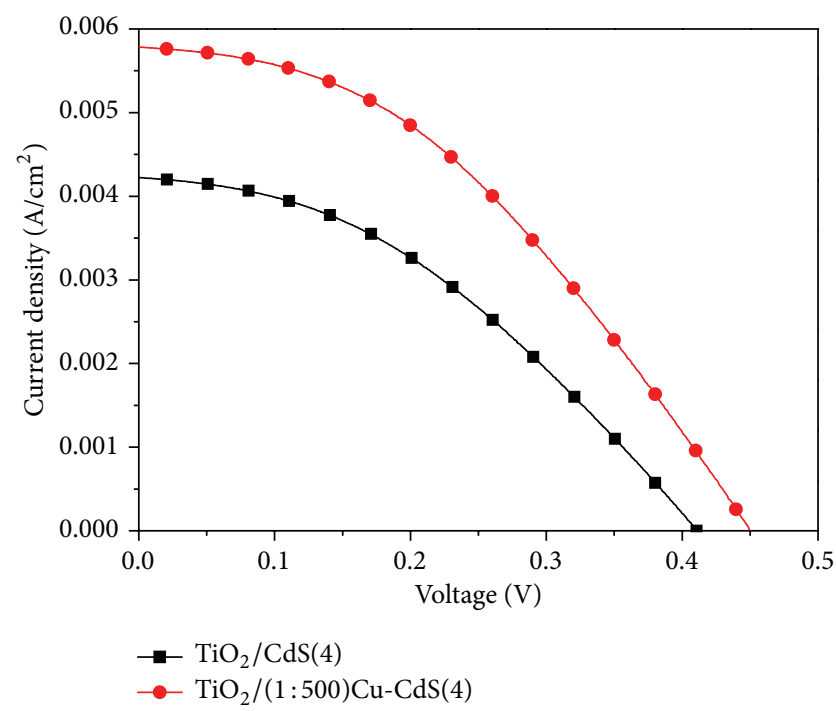

FIgUre 3: The $J-V$ curves of undoped CdS QDSCs and $\mathrm{Cu}$ doped CdS QDSCs.

TABLE 2: The parameters of undoped $\mathrm{CdS}$ and $\mathrm{Cu}$ doped $\mathrm{CdS}$ QDSCs.

\begin{tabular}{lcccc}
\hline Sample & $\begin{array}{c}J_{\text {sc }} \\
\left(\mathrm{mA} / \mathrm{cm}^{2}\right)\end{array}$ & $\begin{array}{c}V_{\text {oc }} \\
(\mathrm{mV})\end{array}$ & FF & $\eta(\%)$ \\
\hline $\mathrm{TiO}_{2} / \mathrm{CdS}(4)$ & 4.28 & 412 & 0.39 & 0.67 \\
$\mathrm{TiO}_{2} /(1: 500) \mathrm{Cu}-\mathrm{CdS}(4)$ & 5.79 & 451 & 0.40 & 1.04 \\
\hline
\end{tabular}

From Figure 3 and Table 2, it can be seen that, in the same SILAR cycle number, $\mathrm{Cu}$ doped $\mathrm{CdS}$ quantum dot sensitized solar cell has higher open circuit voltage, short circuit current density, and photoelectric conversion efficiency than undoped CdS quantum dots sensitized solar cell. The reason for this result is that the doping of $\mathrm{Cu}$ improves the conduction band of CdS quantum dots [11] and assists the photogenerated electron to transport to $\mathrm{TiO}_{2}$. What is more is that the incorporation of $\mathrm{Cu}$ can also improve the adsorption spectra of CdS quantum dots on $\mathrm{TiO}_{2}$ photoanode surface, inhibiting the generation of dark current, finally improving all the parameters of the QDSCs. Figure 4. Energy level diagrams of doped and undoped $\mathrm{TiO}_{2} / \mathrm{CdS}$ QDSCs. From the chart we can intuitively see changes in energy level.

The above contents analyzed $J-V$ curves of the doped and undoped quantum dot sensitized solar cell, and we will discuss the influence of $\mathrm{Cu}$ doping ratio on the quantum dot sensitized solar cell. Figure 5 shows the $J-V$ curves of different doping ratio of $\mathrm{Cu}$ doped CdS QDSCs. Table 3 shows the corresponding parameters of QDSCs.

As can be seen from the charts, when the doping ratio of $\mathrm{Cu}$ is $1: 10$, QDSC's parameters are close to zero. And then with the decrease of the doping ratio, the short circuit current density, the open circuit voltage, and the photoelectric conversion efficiency increase. When the doping ratio is $1: 500$, all the parameters reach the maximum value. While with further decrease in the proportion of $\mathrm{Cu}$ doping, all the parameters of the QDSCs have a decline tendency.

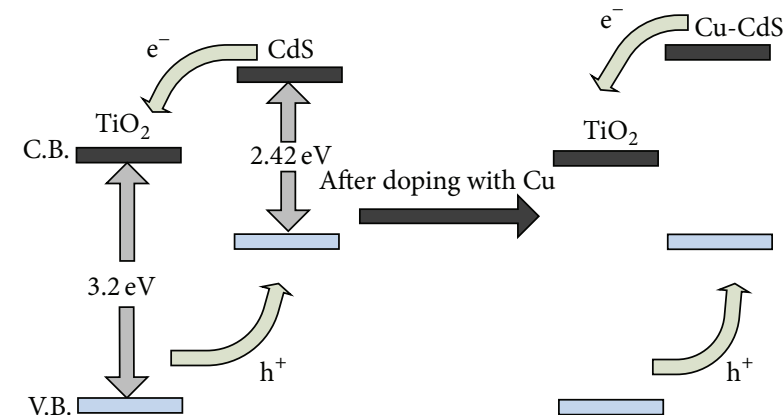

FIGURE 4: Energy level diagrams of doped and undoped $\mathrm{TiO}_{2} / \mathrm{CdS}$.

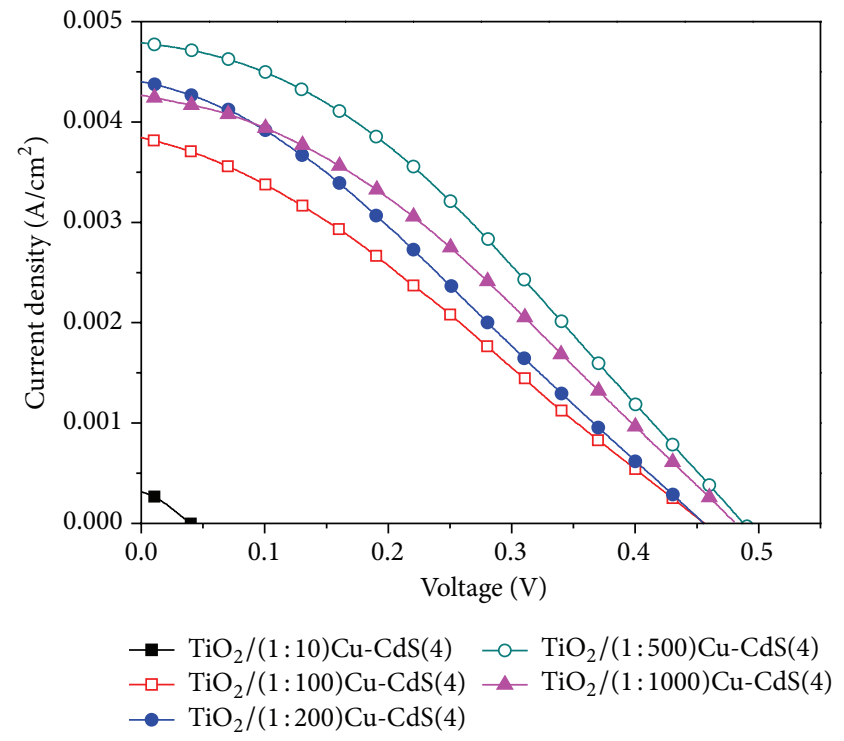

Figure 5: The $J-V$ curves of different doping ratio of $\mathrm{Cu}$ doped $\mathrm{CdS}$ QDSCs.

TABLE 3: The parameters of different doping ratio of $\mathrm{Cu}$ doped $\mathrm{CdS}$ QDSCs.

\begin{tabular}{lcccc}
\hline Doping ratio & $\begin{array}{c}J_{\text {sc }} \\
\left(\mathrm{mA} / \mathrm{cm}^{2}\right)\end{array}$ & $\begin{array}{c}V_{\text {oc }} \\
(\mathrm{mV})\end{array}$ & $\mathrm{FF}$ & $\eta(\%)$ \\
\hline $\mathrm{TiO}_{2} /(1: 10) \mathrm{Cu}-\mathrm{CdS}(4)$ & 0.32 & 40 & 0.31 & 0.004 \\
$\mathrm{TiO}_{2} /(1: 100) \mathrm{Cu}-\mathrm{CdS}(4)$ & 3.85 & 457 & 0.29 & 0.51 \\
$\mathrm{TiO}_{2} /(1: 200) \mathrm{Cu}-\mathrm{CdS}(4)$ & 4.40 & 455 & 0.30 & 0.60 \\
$\mathrm{TiO}_{2} /(1: 500) \mathrm{Cu}-\mathrm{CdS}(4)$ & 4.79 & 488 & 0.35 & 0.81 \\
$\mathrm{TiO}_{2} /(1: 1000) \mathrm{Cu}-\mathrm{CdS}(4)$ & 4.26 & 482 & 0.34 & 0.69 \\
\hline
\end{tabular}

\section{Conclusion}

The doping ratio of $\mathrm{Cu}$ is $1: 10$. And then it decreases the doping ratio, and the short circuit current density, the open circuit voltage, and the photoelectric conversion efficiency increase. When the doping ratio is $1: 500$, all the parameters reach the maximum value. While with further decrease in the proportion of $\mathrm{Cu}$ doping, all the parameters of the QDSCs have a decline tendency. The results show that, in a certain 
range, the lower the doping ratio of $\mathrm{Cu}$, the better the performance of quantum dot sensitized solar cell.

\section{Conflict of Interests}

The authors declare that there is no conflict of interests regarding the publication of this paper.

\section{Acknowledgments}

This work was partially supported by Key Project of Beijing Natural Science Foundation (3131001), Key Project of Natural Science Foundation of China (91233201 and 61376057), Key Project of Beijing Education Committee Science \& Technology Plan (KZ201211232040), State 863 Plan of MOST of PR China (2011AA050527), Beijing National Laboratory for Molecular Sciences (BNLMS2012-21), State Key Laboratory of Solid State Microstructures of Nanjing University (M27019), State Key Laboratory for New Ceramic and Fine Processing of Tsinghua University (KF1210), Key Laboratory for Renewable Energy and Gas Hydrate of Chinese Academy of Sciences (y207ka1001), Beijing Key Laboratory for Sensors of BISTU (KF20141077207 and KF20141077208), and Beijing Key Laboratory for photoelectrical measurement of BISTU (GDKF2013005).

\section{References}

[1] B. O'Regan and M. Graetzel, "Low-cost, high-efficiency solar cell based on dye-sensitized colloidal $\mathrm{TiO}_{2}$ films," Nature, vol. 353, no. 6346, pp. 737-740, 1991.

[2] P. V. Kamat, "Meeting the clean energy demand: nanostructure architectures for solar energy conversion," Journal of Physical Chemistry C, vol. 111, no. 7, pp. 2834-2860, 2007.

[3] J. Y. Kim, K. Lee, N. E. Coates et al., "Efficient tandem polymer solar cells fabricated by all-solution processing," Science, vol. 317, no. 5835, pp. 222-225, 2007.

[4] P. V. Kamat, K. Tvrdy, D. R. Baker, and J. G. Radich, "Beyond photovoltaics: semiconductor nanoarchitectures for liquidjunction solar cells," Chemical Reviews, vol. 110, no. 11, pp. 66646688, 2010.

[5] P. V. Kamat, "Quantum dot solar cells. Semiconductor nanocrystals as light harvesters," The Journal of Physical Chemistry C, vol. 112, no. 48, pp. 18737-18753, 2008.

[6] I. Mora-Seró and J. Bisquert, "Breakthroughs in the development of semiconductor-sensitized solar cells," Journal of Physical Chemistry Letters, vol. 1, no. 20, pp. 3046-3052, 2010.

[7] G. Hodes, "Comparison of dye- and semiconductor-sensitized porous nanocrystalline liquid junction solar cells," Journal of Physical Chemistry C, vol. 112, no. 46, pp. 17778-17787, 2008.

[8] I. J. Kramer and E. H. Sargent, "Colloidal quantum dot photovoltaics: a path forward," ACS Nano, vol. 5, no. 11, pp. 8506-8514, 2011.

[9] J. G. Rowley, B. H. Farnum, S. Ardo, and G. J. Meyer, "Iodide chemistry in dye-sensitized solar cells: making and breaking I-I bonds for solar energy conversion," Journal of Physical Chemistry Letters, vol. 1, no. 20, pp. 3132-3140, 2010.

[10] P. K. Santra and P. V. Kamat, "Mn-doped quantum dot sensitized solar cells: a strategy to boost efficiency over 5\%," Journal of the American Chemical Society, vol. 134, no. 5, pp. 2508-2511, 2012.
[11] M. Wei and Y. Li, "A method of improving the performance of quantum dot sensitized solar cell," China Patent, 201010608155.5, 2011. 

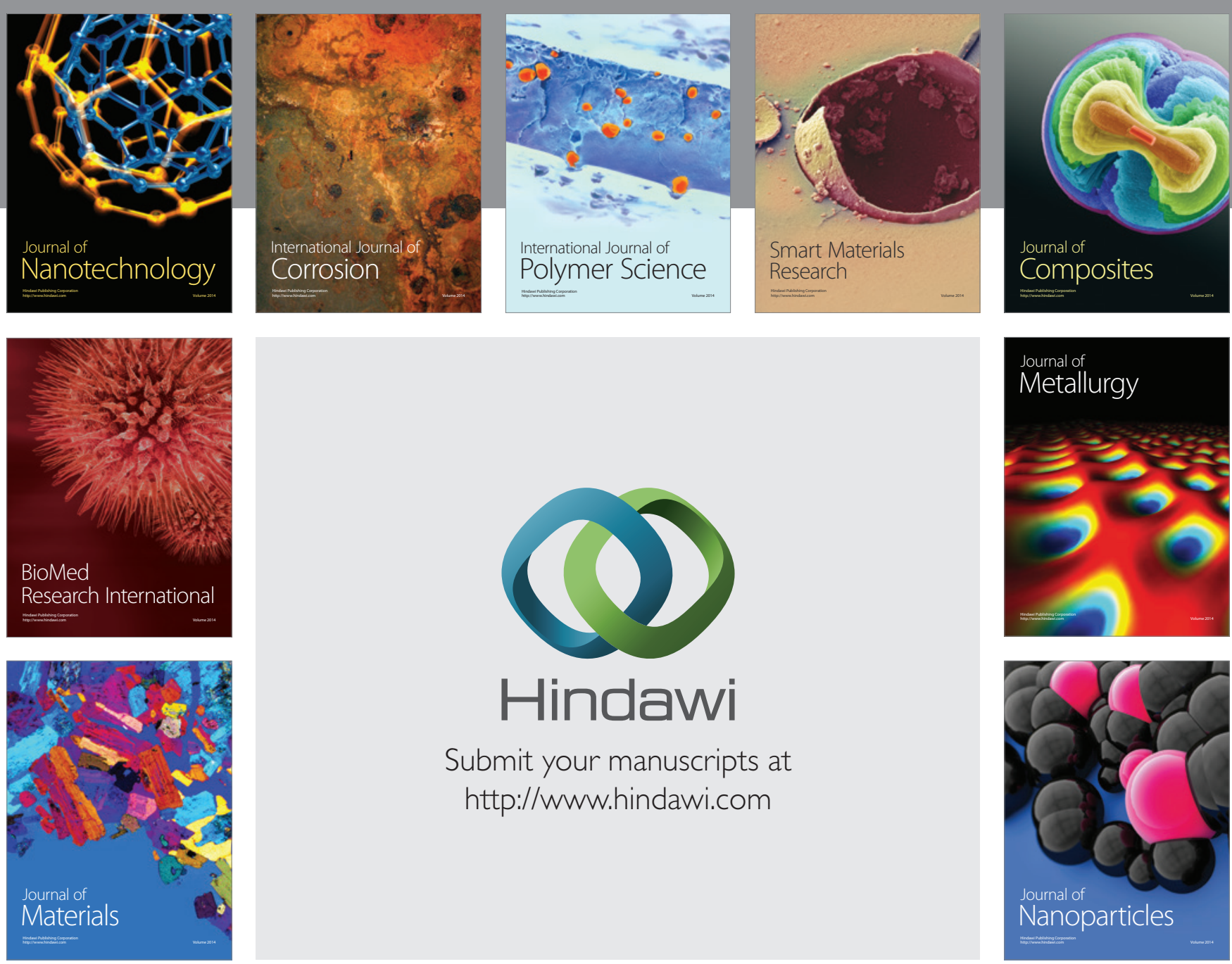

Submit your manuscripts at http://www.hindawi.com
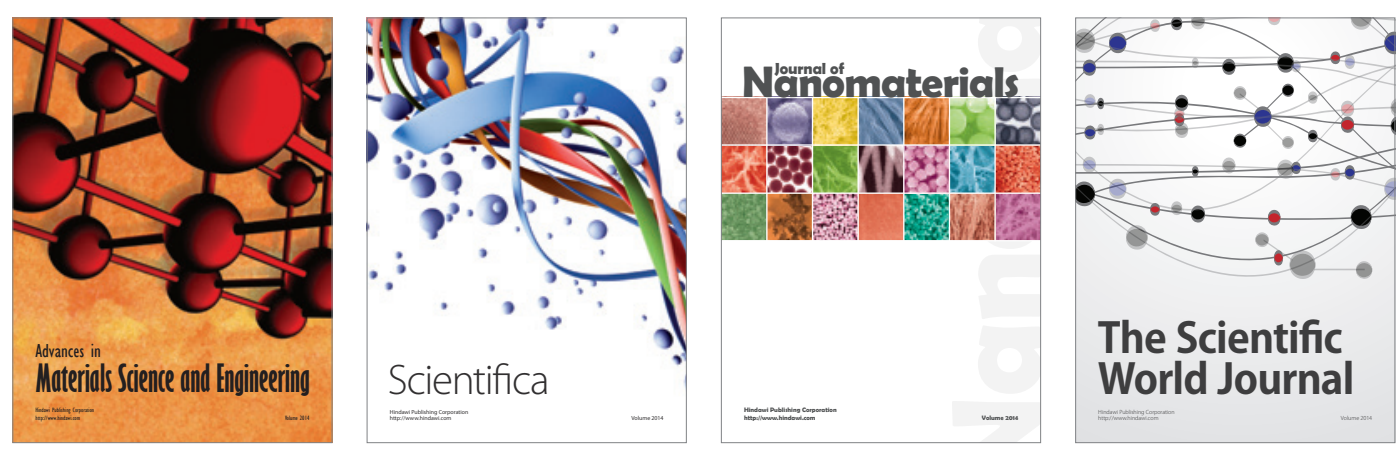

\section{The Scientific World Journal}
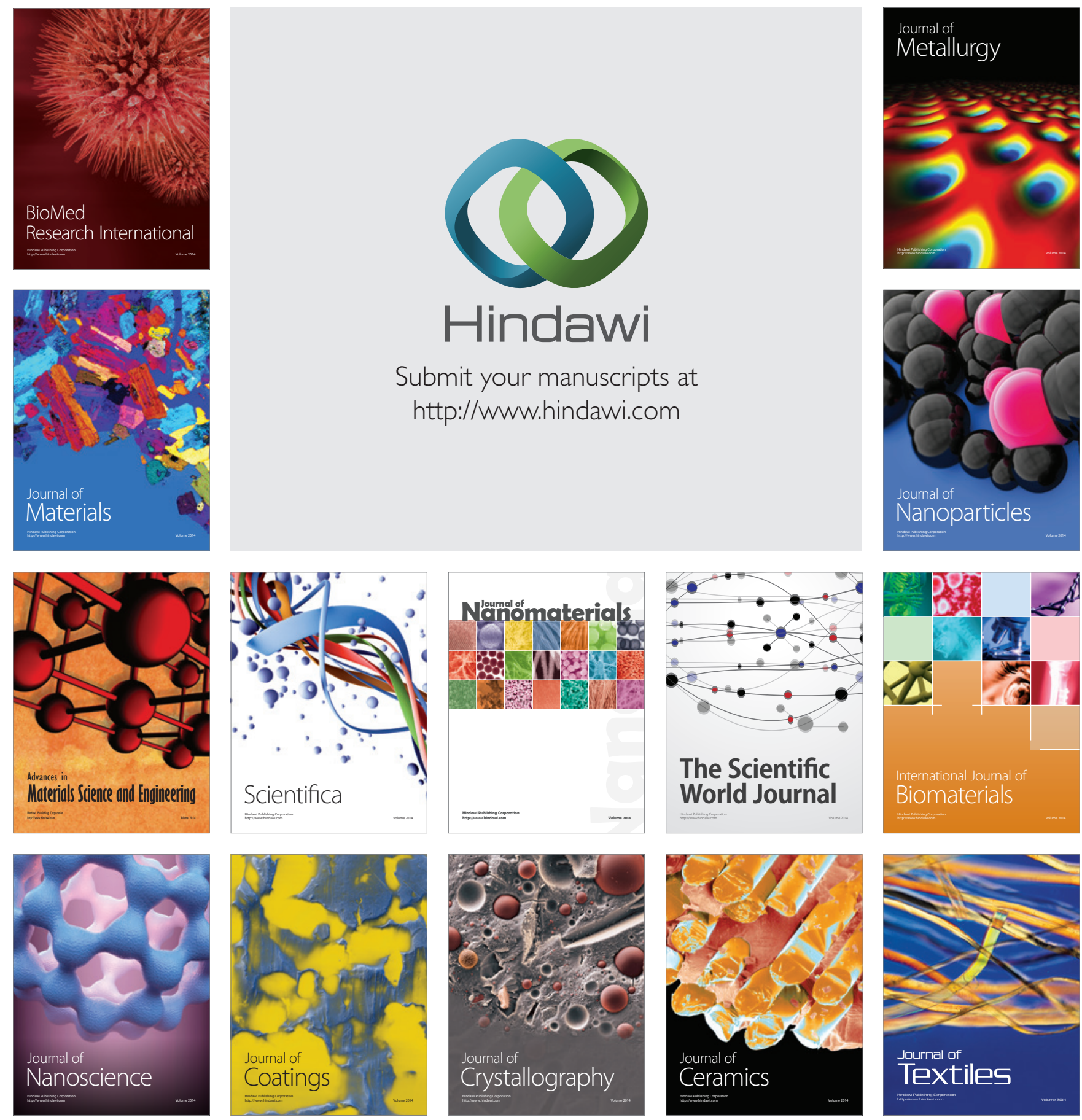